\title{
Effect of Agronomical Manipulations on Carbon Dioxide Emission from Transplanted Rice (Oryza sativa L.) Field under Midland
}

\author{
Sandeep Kumar, Adikant Pradhan*, T. Chandrakar, Manish Kumar and D.P. Singh
}

S.G. College of Agriculture and Research Station, Indira Gandhi Krishi Vishwavidyalaya, Kumhrawand, Jagdalpur (C.G.) 494 005, India

*Corresponding author

\section{A B S T R A C T}

\section{Keywords}

Agronomical manipulations, Carbon dioxide emission, Transplanted rice, Water imponding, Growth parameters

Article Info

Accepted:

10 July 2019

Available Online:

10 August 2019

\begin{abstract}
A field experiment was conducted on rice (var. $\left.\mathrm{MTU}^{-1} 001\right)$ by transplanting of 25 days seedlings during Kharif season 2018 in Inseptisols of Instructional cum Research Farm, S. G. College of Agriculture and Research Station, Kumhrawand, Jagdalpur, Chhattisgarh, India under RCBD (Randomized Complete

Block Design) with four replications. The treatment combinations were Ambika paddy weeder at 20 and 40 day after transplanting, Bispyribac- sodium @ 80g ha ${ }^{-1}$ at 15 day after transplanting, hand weeding twice at 20 and 40 day after transplanting, water imponding of 40 days, 10 days after transplanting, no water imponding alongwith one control (no weeding). Plant height, LAI at $60 \mathrm{DAT}$, Tiller hill ${ }^{-1}$, Panicle hill $^{-1}$, Penicle length $(\mathrm{cm})$, Grains panicle ${ }^{-1}$, CGR $\left(\mathrm{g} \mathrm{plant}^{-1} \mathrm{day}^{-1}\right)$ at 60-90 DAT, RGR $\left(\mathrm{g}\right.$ plant $\left.{ }^{-1} \mathrm{day}^{-1}\right)$ at 60-90 DAT were recorded higher value in hand weeding twice @ 20 and 40 days after transplanting than remaining treatments except bispyribac-sodium @ $80 \mathrm{~g} \mathrm{ha}^{-1}$ at $15 \mathrm{DAT}$ which was at par to that of hand weeding twice. Maximum number of panicle hill $^{-1}$, panicle length, seeds panicle ${ }^{-1}$, and test weight were recorded with hand weeding twice @ 20 and 40 days after transplanting which was significantly superior over rest of treatments, being on par to application of bispyribac-sodium @ $80 \mathrm{~g} \mathrm{ha}^{-1}$ at 15 days after transplanting. Hand weeding twice at 20 and 40 days after transplanting produced significantly higher grain yield $\left(42.79 \mathrm{q} \mathrm{ha}^{-1}\right)$ than rest of treatments except application of bispyribac-sodium @ $80 \mathrm{~g} \mathrm{ha}^{-1}$ at 15 days after transplanting $\left(40.31 \mathrm{q} \mathrm{ha}^{-1}\right.$ ) which were $40.94 \%$ and $32.77 \%$ increased in yield over control. Among the treatments, the highest quantity of $\mathrm{CO}_{2}$ emission from rice field was with hand weeding twice at 20 and 40 DAT $\left(2465.31 \mathrm{~g} \mathrm{day}^{-1} \mathrm{ha}^{-1}\right)$ at 35 DAT and the lowest was recorded when applied bispyribacsodium @ $80 \mathrm{~g} \mathrm{ha}^{-1}$ at 15 DAT $\left(202.98 \mathrm{~g} \mathrm{day}^{-1} \mathrm{ha}^{-1}\right)$ at 45 DAT, which was highest and lowest level of agronomical manipulations in respective treatments reflecting on emission.
\end{abstract}

\section{Introduction}

Rice is the staple food of more than half of world's population. Among the rice growing countries, India has the largest area (44 million hectares) and it is the second largest producer (131 million tonnes) of rice next to China (197 million tonnes). In India, rice occupies an area of $43.95 \mathrm{~m}$ ha with production and productivity of $106.65 \mathrm{mt}$ and $2.4 \mathrm{t} / \mathrm{ha}$, respectively (Anonymous, 2015). The area, production and productivity under rice in
Chhattisgarh is $3.77 \mathrm{~m}$ ha, 3.36 million tonnes and $1.8 \mathrm{t} / \mathrm{ha}$, respectively (Anonymous, 2014). India is the second largest producer and consumer of rice in the world next to China and accounts for $21 \%$ of the world's total rice production even covering more than half of the world's population (FAO, 2009). The Chhattisgarh is known as "rice bowl of India" and about $82 \%$ population of the state is dependent on agriculture for their livelihood. The total rice grown area is 3.61 million hectares with the production of 6.36 million 
tonnes and productivity of 1.8 tonnes $\mathrm{ha}^{-1}$ (Anonymous, 2017). Whereas, in Bastar district, the area under kharif paddy was about 137.60 thousand hectare, production is 244.70 thousand tones with productivity of 1778 $\mathrm{kg} / \mathrm{ha}$ (Anonymous, 2012). In Bastar region, plenty of cultivated lands fall under rice cultivation that covers various types of land situations. The situations like upland, midland and lowland are basic form of rice farming give the opportunity to assess the various systems of rice cultivation on these particular lands; uplands are most drainable condition of soils, further not providing any geo-genic process as compare to midland and lowland farming. The midland and lowland farming have greater time period of water imponding during rainy season and the stagnation of water play an important role in bio-chemical change of cultivated soils. The changes in the process might be assessed through various agronomical manipulations such as water imponding, soil disturbance, vegetation cover affect much to soil and growing habit of rice. This study includes different aspects of gas emission which is directly responsible for all the mentioned process, so the cultivation of rice itself having environment concern and the process of cultivation may be tool to enhancing or reducing the gaseous emission or nongaseous emission from rice fields.

Bastar plateau has unique farming situations divided into Marhaan, Tikra, Maal and Gabhar is used for diverse form of rice cultivation including direct seeding, transplanting and sprouted seed sowing on puddled fields. Biasi (Beushening) in direct seeded rice at 25-35 days after sowing always changes the emission of gases from soil whereas transplanting creates another types of soil environment by puddling might be a pronounced more emissions from the soil with higher disturbance of surface soil. Due to adaptation of various crop establishment methods, growth and development also influences the soil profile by penetrating roots in various capacities to disturb the initial arrangement of soils, which is more important in future aspect of sustainable agriculture in context of climate change from farming.

Globally, rice plays an important role in greenhouse gas emission such as $\mathrm{CO}_{2}$ and $\mathrm{CH}_{4}$ as documented under IPCC (1995). Paddy fields act as an important interface between the atmosphere and the land and carbon dioxide $\left(\mathrm{CO}_{2}\right)$ fixation by photosynthesis provides staple foods to half the world's population, and rice is one of the most important cereal crops, especially in Asian countries (IRRI, 2002). In view of all above aspects; an experiment was carried out during the kharif season of year 2018.

\section{Materials and Methods}

A field experiment was conducted on rice (var. $\mathrm{MTU}^{-1} 001$ ) by transplanting of 25 days seedlings during Kharif season 2018 in Inseptisols of Instructional cum Research Farm, S. G. College of Agriculture and Research Station, Kumhrawand, Jagdalpur, Chhattisgarh, India under RCBD (Randomized Complete Block Design) with four replications. Bastar lies at $19^{0} 10^{\prime} \mathrm{N}$ latitude and $81^{\circ} 95^{\prime}$ E longitude with an altitude of 552 meter above mean sea level. The average annual rainfall of the area is $1359.4 \mathrm{~mm}$ and major amount of precipitation occurs between June to September (1148.6 $\mathrm{mm}$ ) about 3 to 4 months which is the core rice growing seasons. The average annual temperature is $23.45^{\circ} \mathrm{C}$ and rainfall of 2018 was recorded from the meteorological observatory. Available N, P and K of the experimental field were $284.5 \mathrm{~kg} \mathrm{ha}^{-1}, 8.84 \mathrm{~kg}$ $\mathrm{ha}^{-1}$ and $255.50 \mathrm{~kg} \mathrm{ha}{ }^{-1}$, respectively. $p \mathrm{H}$ (1:2.5 of soil: water), EC and Organic Carbon were also analysed $6.5,0.40 \mathrm{dS} \mathrm{m}^{-1}, 0.52 \%$. The treatment combinations were Ambika paddy weeder at 20 and 40 day after 
transplanting, Bispyribac-sodium @ 80g ha ${ }^{-1}$ at 15 day after transplanting, hand weeding twice at 20 and 40 day after transplanting, water imponding of 40 days, 10 days after transplanting, no water imponding along with one control (no weeding). A fertilizer dose of 80:60:40 Kg N: P: $\mathrm{K} \mathrm{ha}^{-1}$ for rice was used by splitting as $50 \%$ basal dose of nitrogen and $100 \%$ recommended dose of phosphorus and potassium applied and remaining nitrogen was supplied in two parts at tillering and panicle initiation stages of the crop.

Carbon dioxide $\left(\mathrm{CO}_{2}\right)$ emission from each treatment was recorded at 5 days interval till 90 days from the date of transplanting. $\mathrm{CO}_{2}$ emission from each treatment was absorbed by $0.5 \mathrm{~N} \mathrm{NaOH}$ solution which is collected in airtight test tube and titrates with $0.1 \mathrm{~N} \mathrm{H}_{2} \mathrm{SO}_{4}$ solution. For measuring $\mathrm{CO}_{2}$ emission, PVC pipe of 6 inch diameter was designed as per the need by making three rows of perforated hole $(2 \mathrm{~cm}$ diameter) in bottom periphery of PVC pipes in bottom 3 inch width for better movement of soil gases. The PVC pipes were inserted at centre of each plot a depth of 10 inch in soil profile. The PVC pipe was in height of $1.0 \mathrm{~m}$, and top was tightly closed by rubber band keeping impermeable polythene cover, one hole was made to draw $\mathrm{CO}_{2}$ from stored PVC pipe at certain time interval by syringe of $5 \mathrm{ml}$ capacity and immediately titrate at field (Figure 1). Data were subjected to statistical analysis as per the procedure laid down by (Gomez and Gomez, 1984).

\section{Results and Discussion}

\section{Effect on Growth parameters}

Plant height, LAI at 60 DAT, Tiller hill ${ }^{-1}$, Panicle hill ${ }^{-1}$, Penicle length $(\mathrm{cm})$, Grains panicle $^{-1}$, CGR (g plant ${ }^{-1}$ day $^{-1}$ ) at 60-90 DAT, RGR (g plant ${ }^{-1}$ day $^{-1}$ ) at 60-90 DAT were recorded higher value in hand weeding twice ( 20 and 40 days after transplanting than remaining treatments except bispyribacsodium@80 $\mathrm{g} \mathrm{ha}^{-1}$ at 15 DAT which was at par to that of hand weeding twice Kristof et al., (2014) concluded that no-tillage; direct drilling technology caused the lowest carbon dioxide emissions released from soil into the atmosphere in comparison with other tested technologies.

Reduced tillage technology caused higher amount of $\mathrm{CO} 2$ emissions then no-tillage and lower value was found in control plot throughout observations (Table 1).

\section{Effect on yield and yield attributes}

Maximum number of panicle hill $^{-1}$ was recorded with hand weeding twice @ 20 and 40 days after transplanting (5.41) which was significantly superior over rest of treatments, being on par to application of bispyribacsodium @ $80 \mathrm{~g} \mathrm{ha}^{-1}$ at 15 days after transplanting (5.33). Ambika paddy weeder at 20 and 40 DAT (4.66) and water imponding of 40 days 10 days after transplanting (4.58) were at par with each other in attaining number of panicles hill ${ }^{-1}$. The minimum number of panicles hill ${ }^{-1}$ was observed in no weeding (3.98). Similar trend was noticed with panicle length. Two hand weeding increased panicles and its length significantly over remaining treatments due to higher number of tillers which converted further into panicle helps in increasing number and application of bispyribac-sodium also showed similar in producing panicles being statistically resemblance. Similar results have been reported by (Gill et al., 1992). On other hands, seed panicle ${ }^{-1}$ was higher when two hand weeding was done at 20 and 40 DAT having significantly more than control (98.83) and on par with Ambika paddy weeder at 20 and 40 DAT (127.17), bispyribac-sodium @ $80 \mathrm{~g} \mathrm{ha}^{-1}$ at 15 days after transplanting (128.00) and water imponding of 40 days, 10 days after transplanting. 


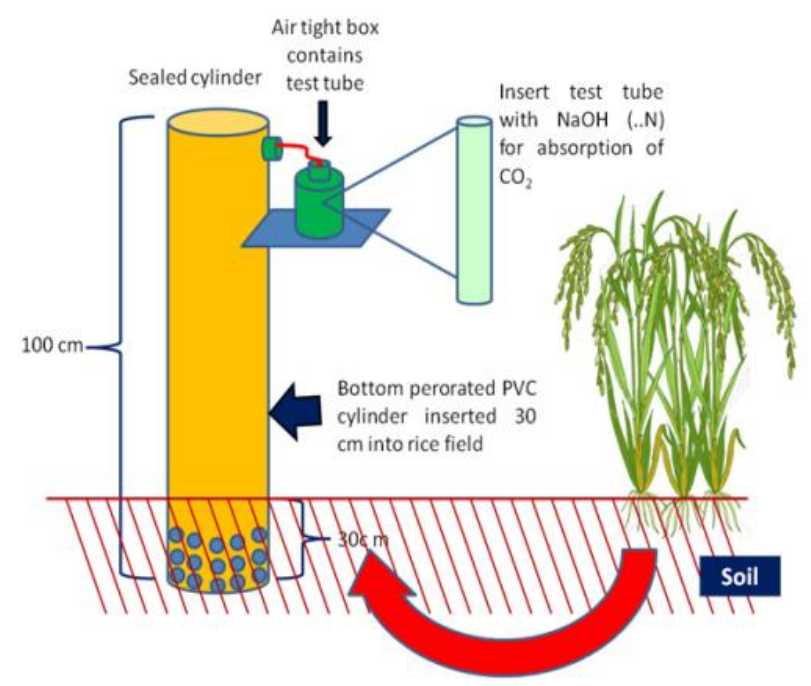

Figure 1. Schematic diagram for $\mathrm{CO}_{2}$ measurement

Table.1 Effect of agronomical manipulation on growth and yield attributes of rice

\begin{tabular}{|c|c|c|c|c|c|c|c|c|}
\hline Treatment & $\begin{array}{l}\text { Plant } \\
\text { height }\end{array}$ & $\begin{array}{l}\text { LAI } \\
\text { at } 60 \\
\text { DAT }\end{array}$ & $\begin{array}{l}\text { Tiller } \\
\text { hill }^{-1}\end{array}$ & $\begin{array}{l}\text { Panicle } \\
\text { hill }^{-1}\end{array}$ & $\begin{array}{l}\text { Panicle } \\
\text { length } \\
(\mathrm{cm})\end{array}$ & $\begin{array}{l}\text { Grains } \\
\text { panicle }^{-1}\end{array}$ & $\begin{array}{c}\text { CGR (g plant } \\
1 \text { day }^{-1} \text { ) at 60- } \\
90 \text { DAT }\end{array}$ & $\begin{array}{l}\text { RGR (g plant }{ }^{-1} \\
\text { day }^{-1} \text { ) at } 60-90 \\
\text { DAT }\end{array}$ \\
\hline$T_{1}$ & 96.51 & 3.37 & 6.21 & 4.66 & 19.68 & 127.17 & 0.22 & 0.01 \\
\hline $\mathbf{T}_{2}$ & 97.38 & 3.77 & 6.80 & 5.33 & 20.32 & 128.00 & 0.27 & 0.01 \\
\hline $\mathbf{T}_{3}$ & 98.73 & 3.89 & 7.35 & 5.41 & 21.32 & 132.50 & 0.33 & 0.01 \\
\hline $\mathbf{T}_{4}$ & 96.01 & 3.24 & 6.15 & 4.58 & 19.06 & 125.00 & 0.22 & 0.01 \\
\hline$T_{5}$ & 95.50 & 3.09 & 5.81 & 4.39 & 19.02 & 119.42 & 0.23 & 0.01 \\
\hline$T_{6}$ & 92.50 & 2.93 & 5.41 & 3.98 & 18.09 & 98.83 & 0.20 & 0.01 \\
\hline SEm \pm & 0.12 & 0.11 & 0.07 & 0.12 & 0.48 & 1.73 & 0.02 & 0.00 \\
\hline $\mathrm{CD}(\mathrm{P}=\mathbf{0 . 0 5})$ & 0.37 & 0.35 & 0.22 & 0.38 & 1.47 & 5.28 & 0.07 & NS \\
\hline
\end{tabular}

Table.2 Effect of agronomical manipulations on yield of rice

\begin{tabular}{|c|c|c|c|}
\hline Treatments & $\begin{array}{l}\text { Grain Yield } \\
\left(\mathrm{q} \mathrm{ha}^{-1}\right)\end{array}$ & $\begin{array}{l}\text { Straw Yield } \\
\left(\mathrm{q} \mathrm{ha} \mathbf{h}^{-1}\right)\end{array}$ & $\begin{array}{l}\text { Harvest } \\
\text { Index }(\%)\end{array}$ \\
\hline$T_{1}$ : Ambika paddy weeder at $20 \& 40$ days after transplanting & 38.84 & 43.48 & 47.12 \\
\hline $\begin{array}{l}\mathrm{T}_{2}: \text { Bispyribac sodium @ } 80 \mathrm{~g} \mathrm{ha}^{-1} \text { at } 15 \text { days after } \\
\text { transplanting }\end{array}$ & 40.31 & 45.80 & 46.76 \\
\hline$T_{3}:$ Hand weeding twice at $20 \& 40$ days after transplanting & 42.79 & 48.16 & 47.05 \\
\hline $\mathrm{T}_{4}:$ Water imponding of 40 days $10 \mathrm{DAT}$ & 37.42 & 42.76 & 46.63 \\
\hline$T_{5}:$ No water imponding & 35.32 & 42.28 & 45.44 \\
\hline$T_{6}:$ Control (no weeding) & 30.36 & 40.95 & 42.66 \\
\hline SEm \pm & 1.09 & 0.87 & 0.87 \\
\hline $\mathrm{CD}(\mathrm{P}=\mathbf{0 . 0 5})$ & 3.32 & 2.67 & 2.66 \\
\hline
\end{tabular}


Table.3 Effect of agronomical manipulation on $\mathrm{CO}_{2}$ emission from rice field

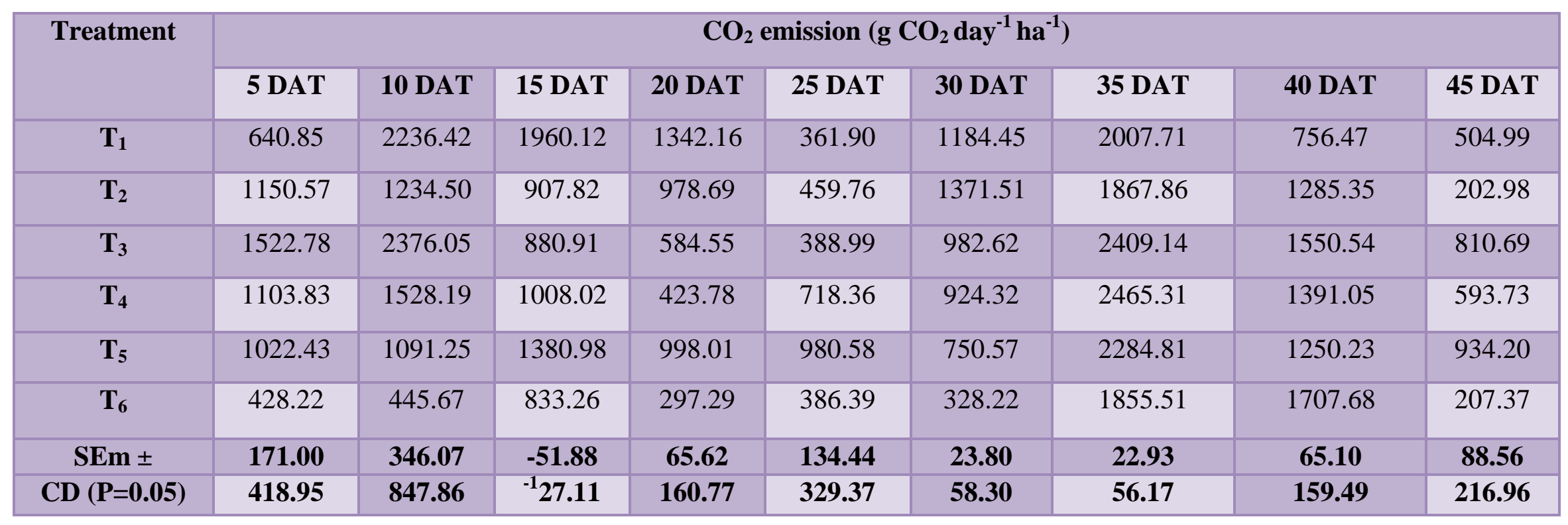

Table.4 Effect of agronomical manipulation on $\mathrm{CO}_{2}$ emission from rice field

\begin{tabular}{|c|c|c|c|c|c|c|c|c|c|c|}
\hline \multirow[t]{2}{*}{ Treatment } & \multicolumn{10}{|c|}{$\mathrm{CO}_{2}$ emission $\left(\mathrm{g} \mathrm{CO}_{2} \mathrm{day}^{-1} \mathrm{ha}^{-1}\right)$} \\
\hline & 50 DAT & 55 DAT & $60 \mathrm{DAT}$ & 65 DAT & 70 DAT & 75 DAT & 80 DAT & 85 DAT & 90 DAT & Mean \\
\hline $\mathbf{T}_{1}$ & 441.79 & 577.67 & 571.91 & 505.25 & 742.01 & 733.72 & 468.53 & 416.17 & 1015.79 & 914.88 \\
\hline $\mathbf{T}_{2}$ & 520.60 & 613.80 & 391.26 & 311.31 & 739.27 & 770.20 & 419.67 & 422.61 & 896.10 & 807.99 \\
\hline $\mathbf{T}_{3}$ & 894.90 & 1027.44 & 994.92 & 970.26 & 757.24 & 581.64 & 319.56 & 376.94 & 1232.89 & 1036.78 \\
\hline $\mathbf{T}_{4}$ & 462.71 & 365.72 & 605.87 & 932.87 & 620.03 & 494.36 & 390.31 & 288.44 & 1157.99 & 859.72 \\
\hline $\mathbf{T}_{5}$ & 1088.45 & 1645.46 & 1053.42 & 297.94 & 516.82 & 489.17 & 322.87 & 481.65 & 1614.82 & 1011.31 \\
\hline $\mathbf{T}_{6}$ & 349.20 & 551.15 & 421.11 & 412.03 & 213.80 & 302.93 & 219.58 & 364.09 & 936.77 & 570.02 \\
\hline SEm \pm & 176.40 & 270.09 & 158.80 & 15.26 & 56.00 & 35.62 & 28.88 & 36.12 & 30.57 & 72.27 \\
\hline $\mathrm{CD}(\mathrm{P}=0.05)$ & 432.19 & 661.72 & 389.05 & 37.39 & 137.21 & 87.28 & 70.75 & 88.50 & 74.90 & 177.06 \\
\hline
\end{tabular}


Seedes panicle ${ }^{-1}$ was found to be higher in all treatments except control (98.83), because these treatments are positively suppressing the other flora available in vicinity of crop increased seed per panicle (Mamun, 1988). Test weight of rice was not significantly influenced by imposing treatments (Table 1) and data indicated that hand weeding twice (20 and 40 DAT) gave higher test weight $(25.52 \mathrm{~g})$ and the lowest was in control treatment $(23.69 \mathrm{~g})$ owing to higher magnitude of unsuppressed growth of crop led to little higher test weight with two hand weeding which was not found significant.

Hand weeding twice at 20 and 40 days after transplanting produced significantly higher grain yield $\left(42.79 \mathrm{q} \mathrm{ha}^{-1}\right)$ than rest of treatments except application of bispyribacsodium @80 $\mathrm{g} \mathrm{ha}^{-1}$ at 15 days after transplanting $\left(40.31 \mathrm{q} \mathrm{ha}^{-1}\right)$ which were $40.94 \%$ and $32.77 \%$ increase in yield over control under influence of hand weeding twice (20 and 40 DAT) and bispyribacsodium@80 $\mathrm{g} \mathrm{ha}^{-1}$ at 15 DAT, respectively. Whereas, Ambika paddy weeder at 20 and 40 DAT and water imponding of 40 days, 10 days after transplanting were statistically similar in producing grain yield. The lowest grain yield was recorded with control plot $\left(30.36 \mathrm{q} \mathrm{ha}^{-1}\right)$. The higher grain yield was produced by two hand weeding which is directly depend on various growth and yield parameters expressing their integrated influence with the increment in supply of proper growth resources to rice crop, thus improved yield component as a result higher grain yield was obtained. These findings are also similar to Gill et al., (1992). Similar trend was followed with straw yield. The straw yield and HI (harvest index) was higher again with two hand weeding at 20 and 40 DAT (48.16 q ha ${ }^{-1}$ and $\left.47.05 \%\right)$ followed by bispyribac-sodium @80 $\mathrm{g} \mathrm{ha}^{-1}$ at 15 DAT (45.80 q ha ${ }^{-1}$ and 46.76). Hand removal of weeds from rice field at 20 and 40 DAT may also improve rice grain and straw yield by providing weed free environment led to availability of growth resources. Similar results reported by Mishra (2016).

Maximum Harvest Index (HI) was recorded with Ambika paddy weeder at 20 and 40 days after transplanting (47.12\%) which was significantly superior and comparable to hand weeding twice at 20 and 40 DAT (47.05\%), bispyribac-sodium @80 g ha ${ }^{-1}$ at 15 DAT (46.76\%), water imponding of 40 days, 10 days after transplanting (46.63\%) and no water imponding $(45.44 \%)$. The lowest $\mathrm{HI}$ was recorded with control $(42.66 \%)$. The significantly higher HI was recorded with Ambika paddy weeder may be due to decreasing straw yield as compared to other treatments (Table 2).

\section{Effect of agronomical manipulations on $\mathrm{CO}_{2}$ emission}

Data on $\mathrm{CO}_{2}$ emission as influenced by agronomical manipulation was recorded from 5 days after transplanting to 90 days after transplanting at 5 days interval (Table 3). In general, emission of $\mathrm{CO}_{2}$ under influences of agronomical manipulations changed markedly in quantity of $\mathrm{CO}_{2}$ with advancing growth stages, which was significant in emission. Ambika paddy weeder at 20 and 40 days after transplanting emitted lesser quantity of $\mathrm{CO}_{2}$ initial 5 days but sharp increased from 10 DAT to 35 DAT which was gradually decreased further and rise in 90 DAT. Application of bispyribac-sodium @ $80 \mathrm{~g} \mathrm{ha}^{-1}$ at 15 days after transplanting had higher emission of $\mathrm{CO}_{2}$ during $5^{-1} 0$ DAT and 30-40 DAT, and remaining time of observation emission was less, whereas hand weeding twice at 20 and 40 DAT showed significant variation in emission with time and increment of biomass was more pronounce during $5^{-1} 0$ DAT, 30-40 DAT, at 50 DAT and 90 DAT particularly. 
Water imponding of 40 days, 10 days after transplanting and no water imponding were similar in releasing $\mathrm{CO}_{2}$ from rice field during $5^{-1} 5$ DAT, 30-35 DAT, 55-60 DAT and at 90 DAT. The control plot emitted more only during 35-40 DAT and 90 DAT. This might be due to rising temperature and warmer weather. Zebarth et al., (2009) reported emission of $\mathrm{CO}_{2}$ was higher in warmer weather which vary with soil $\mathrm{pH}$, moisture content, $\mathrm{O}_{2}$ supply and $\mathrm{N}$ availability as all these factors have profound effect on soil microbial dynamics and activity. Among the treatments, the highest quantity of $\mathrm{CO}_{2}$ emission from rice field was with hand weeding twice at 20 and 40 DAT (2465.31 g day $^{-1} \mathrm{ha}^{-1}$ ) at 35 DAT and the lowest was recorded when applied bispyribac-sodium @ $80 \mathrm{~g} \mathrm{ha}^{-1}$ at 15 DAT (202.98 $\left.\mathrm{g} \mathrm{day}^{-1} \mathrm{ha}^{-1}\right)$ at 45 DAT, which was highest and lowest level of agronomical manipulations in respective treatments reflecting on emission. At 5 and 10 DAT, higher quantity of $\mathrm{CO}_{2}$ emitted in two hand weddings was done at 20 and 40 DAT on 5 DAT (1522.78 $\left.\mathrm{g} \mathrm{day}^{-1} \mathrm{ha}^{-1}\right)$ and 10 DAT (2376.05 $\left.\mathrm{g} \mathrm{day}^{-1} \mathrm{ha}^{-1}\right)$, further the emission process slowed down till 85 DAT except at 35 DAT, 40 DAT, 55 DAT, and 90 DAT the emission was more over the period of observations. However, no water imponding treatment was emitted significantly higher $\mathrm{CO}_{2}(980.50,934.20,1088.45,1645.46$ and $1053.42 \mathrm{~g} \mathrm{day}^{-1} \mathrm{ha}^{-1}$ at $25,45,50,55$ and 60 DAT, respectively) than remaining treatments again it was increased emission of $\mathrm{CO}_{2}$ significantly at 85 DAT (481.65 $\mathrm{g} \mathrm{day}^{-1} \mathrm{ha}^{-1}$ ) and 90 DAT (1614.82 $\left.\mathrm{g} \mathrm{day}^{-1} \mathrm{ha}^{-1}\right)$. No manipulation was undertaken in experiment had less emission of $\mathrm{CO}_{2}$ then remaining treatments except at 40 DAT where the treatment increased (1707.68 $\left.\mathrm{g} \mathrm{day}^{-1} \mathrm{ha}^{-1}\right)$ emission and found significant at this particular stage of crop growth. Koizumi et al., (2001) observed $\mathrm{CO}_{2}$ exchange through paddy water is the result of photosynthesis of aquatic plants and respiration of both the plants and the soil microorganism. Cheng et al., (2009) and Kogel-Knabner et al., (2010) also indicated that the management induced change of anaerobic and aerobic conditions results in temporal and spatial (vertical and horizontal) variations in reduction and oxidation (redox) reactions affecting the emission (Table 3).

Use of Ambika paddy weeder twice had higher emission (2007.71 $\left.\mathrm{g} \mathrm{day}^{-1} \mathrm{ha}^{-1}\right)$ at 35 DAT then at 10 DAT (2236.42 $\left.\mathrm{g} \mathrm{day}^{-1} \mathrm{ha}^{-1}\right)$, 15 DAT (1960.12 $\left.\mathrm{g} \mathrm{day}^{-1} \mathrm{ha}^{-1}\right), 20$ DAT (1342.16 $\left.\mathrm{g} \mathrm{day}^{-1} \mathrm{ha}^{-1}\right), 30$ DAT $(1184.45 \mathrm{~g}$ day $^{-1} \mathrm{ha}^{-1}$ ) and 90 DAT (1015.79 $\left.\mathrm{g} \mathrm{day}^{-1} \mathrm{ha}^{-1}\right)$ being significantly superior in emission of $\mathrm{CO}_{2}$ at 15 and 20 DAT over rest of treatments. Application of bispyribac-sodium @ $80 \mathrm{~g} \mathrm{ha}^{-1}$ at 15 DAT showed less emission as compared to others having higher value of $1867.86 \mathrm{~g} \mathrm{day}^{-1} \mathrm{ha}^{-1}$ to lower value of $202.98 \mathrm{~g}$ day $^{-1} \mathrm{ha}^{-1}$ within the treatment due to less soil disturbance after transplanting and emission pathway was not developed as in other treatments. Water imponding and no water imponding were not much differed in emission of $\mathrm{CO}_{2}$ from field throughout crop period and observed higher emission in initial first 15 days after transplanting which was higher with water imponding of 40 days, 10 days after transplanting (2465.31 $\mathrm{g} \mathrm{day}^{-1} \mathrm{ha}^{-1}$ ) being at par to hand weeding twice $(2409.14 \mathrm{~g}$ day $\left.^{-1} \mathrm{ha}^{-1}\right)$ and no water imponding $(2284.81 \mathrm{~g}$ day $^{-1} \mathrm{ha}^{-1}$ ) (Table 4). Rahman et al., (2017) observed that reduced tillage also can play an important role in accumulating carbon in the soil. The soil is a major source of emission for atmospheric $\mathrm{CO}_{2}$ content.

\section{References}

Anonymous (2012) Agricultural Statistics at a Glance. Directorate of Economics and Statistics, Department of Agriculture and Cooperation. Pp. 65-66.

Anonymous (2014) Agricultural Statistics at a 
Glance. Ministry of Agriculture and Farmers Welfare. Department of Agriculture, Cooperation and Farmers Welfare. Directorate of Economics and Statistics. Govt. of India, New Delhi. India. pp. 152.

Anonymous (2017) agricultural statistics at a glance. Ministry of Agriculture and Farmers Welfare. Department of Agriculture, Cooperation and Farmers Welfare. Directorate of Economics and Statistics. Govt. of India, New Delhi. India.

Baker J.T. and Allen, L.H. (1993).effects of $\mathrm{CO}_{2}$ and temperature on rice: a summary of five growing season, department of agronomy, institute of food and agricultural sciences. Journal of Agr. Met. 48(5): 575- 582.

Cheng YQ, Yang LZ, Cao ZH, Ci E, Yin SX (2009) Chronosequential changes of selected pedogenic properties in paddy soils as compared with non-paddy soils. Geoderma 151: 31-41.

FAO, Food and Agricultural Organization of the United Nations, (2009) OECDFAO Agricultural Outlook, 2011-2030.

Gill, S. S, Cowles, E. A. and Pietrantonio, P. V. (1992). The mode of action of Bacillus thuringiensis endotoxins. Annual Reveiw of Entomology, 37: 615-636.

Gomez, K. A. and Gomez, A. A. (1984). Statistical procedures for agricultural research (2 ed.). John Wiley and sons, New York, 680p.

International Panel on Climate Change (IPCC). (1995). Climate Change 1995: The Science of Climate Change. In: Houghton, J.T.; Meira Filho, L.G.; Callander, B.A.; Harris, N.; Kattenberg, A. and Maskell, K. (Eds.), Cambridge Univ. Press, Cambridge.

International Rice Research Institute (IRRI). (1993). IRRI Rice Almanac, IRRI, Los BanÄos, Philippines.
Kogel-Knabner, I., Amelung, W., Cao, Z.H., Fiedler, S. and Frenzel, P. (2010) Biogeochemistry of paddy soils. Geoderma 157: 1-14.

Koizumi, H. Kibe, T. Mariko, T. (2001) "Effect of free-air $\mathrm{CO}_{2}$ enrichment (FACE) on $\mathrm{CO}_{2}$ exchange at the floodwater surface in a rice paddy field," New Phytologist, vol. 150, no.2, pp. 231-239.

Krištof K., Šima T., Nozdrovicky L. and Findura, P. (2014). The effect of soil tillage intensity on carbon dioxide emissions released from soil into the atmosphere Agronomy Research 12(1):115-120,

Krištof, K., Buc, M., Nozdrovicky, L. and Šima, T. (2011). Vplyv technologie spracovania pody na množstvo uvol'ňovanych emisii $\mathrm{CO}_{2} \mathrm{z}$ pody do atmosfery. In: XIII. International conference of youngs cientists 2011, Praha, 19.-20. zařri 2011. Praha: ČZU Praha. pp 111-115. ISBN 978-80-2132194-6 (in Slovak, English abstract).

Lal, R., Reicosky, D.C. and Hanson, J.D. (2007). Evolution of the plough over 10,000 years and the rationale forno-till farming. Soil \& Tillage Research 93, 112.

Mamun, A.A. (1988). Farmers' concepts of weeds and weed control in Jawar village in Kishoregonj. Agricultural and Rural Development in Bangladesh. Japan Intl. Cooperation Agency, Dhaka, Bangladesh. JSARD Pub. No 8. pp. 7778.

Mishra, L. N. (2016). Assessment of chemical and non-Chemical Weed management strategies in direct- Seeded aerobic rice (Oryza sativa L.). M.Sc. (Ag.) Thesis. Indira Gandhi Krishi Vishwavidyalaya, Raipur.

Patel, N. R., Dadhwal, V. K. and Saha, S. K. (2011). Measurement and scaling of carbon dioxide $\left(\mathrm{CO}_{2}\right)$ exchanges in 
wheat using fluxtower and remote sensing. J. Ind. Soc. Remote Sensing, doi: 10.1007/s12524-011-0107 ${ }^{-1}$.

Pathak H, Upadhyay RC, Muralidhar M, Bhattacharyya $\mathrm{P}$ and Venkateswarlu B (Eds.). (2013). Measurement of Greenhouse Gas Emission from Crop, Livestock and Aquaculture. Indian Agricultural Research Institute, New Delhi pp 1-114.

Rahman, M.M. Biswas, J. C. Maniruzzaman M. Choudhury A.K. and. Ahmed, F.
(2017). Effect of Tillage Practices and Rice Straw Management on Soil Environment and Carbon Dioxide Emission. The Agriculturists 15(1): 127-142.

Zebarth, B.J., C.F. Drury, N. Tremblay, and A.N. Cambouris. (2009). Opportunities for improved fertilizer nitrogen management in production of arable crops in eastern Canada: A review. Canadian Journal of Soil Science 89: $113-132$.

\section{How to cite this article:}

Sandeep Kumar, Adikant Pradhan, T. Chandrakar, Manish Kumar and Singh, D.P. 2019. Effect of Agronomical Manipulations on Carbon Dioxide Emission from Transplanted Rice (Oryza sativa L.) Field under Midland. Int.J.Curr.Microbiol.App.Sci. 8(08): 943-951. doi: https://doi.org/10.20546/ijcmas.2019.808.110 